\title{
DETERMINATION OF STATIC CHARACTERISTICS OF FLOW FLOTATION MACHINES BASED ON EXPERIMENTS OF THE KINETICS OF THE BATCH COAL FLOTATION
}

\section{WYZNACZANIE CHARAKTERYSTYK STATYCZNYCH FLOTOWNIKÓW PRZEPLYWOWYCH NA PODSTAWIE BADAŃ KINETYKI FLOTACJI CYKLICZNEJ WĘGLA}

\begin{abstract}
In the theory and a simulation technique of a coal flotation process a density function of a distribution of particles flotability is widely used. The characteristics of this type in the design of the flotation circuits as well as to optimize of the settings of the industrial flotation machines may be used. The density function of the distribution of the fraction $f(k)$ based on the kinetics experiments to measure the recovery of material as a function of time in the laboratory flotation machines (in the batch coal flotation process) is determined. The problems of the determining of the flotability spectrum are relatively well resolved. An important problem is the determination of the concentrate quality. The concentrate quality directly depends on the ash content in the concentrate. In the paper a mathematical model of the separation of the mass of ash at the process of the kinetics of the batch flotation has been proposed. The research at different values of the air flow rate was carried out. The results of the analyses in tables and graphs are shown. The static characteristics of the single-cell of the flow flotation machine based on the characteristics of the distribution density of the fraction $f(k)$ and the distribution of the ash content $a_{k}(k)$ were determined. Knowledge of these relationships will allow for a better assessment of the phenomena occurring in the enrichment process. This may be one of the basic information used in the supervisory control system of the flotation process.
\end{abstract}

Keywords: models of the flotation kinetics, coefficient of the flotation velocity, density function of flotability distribution of the coal particles, flow flotation machine, static characteristics of the flow flotation machines

W teorii i technice symulacji procesu flotacji węgla szerokie zastosowanie znajduje funkcja gęstości rozkładu flotowalności ziaren. Charakterystyki tego typu mogą być wykorzystane przy projektowaniu układów technologicznych flotacji jak również do optymalizacji nastaw układów flotowników przemysłowych. Funkcję gęstości rozkładu frakcji $f(k)$ wyznacza się na podstawie przebiegu kinetyki wydzielania się koncentratu we flotownikach laboratoryjnych (w procesie flotacji cyklicznej węgla). Problemy wyznaczania widma flotowalności są stosunkowo dobrze rozwiązane. Istotnym staje się problem wyznaczania jakości koncentratu a o tym decyduje przede wszystkim zawartość popiołu w koncentracie. Autorzy opracowania podjęli próbę stworzenia modelu matematycznego wydzielania się masy popiołu w procesie kinetyki flotacji cyklicznej przy różnych dawkach powietrza aeracyjnego. Wyniki przykładowych analiz przedstawiono

\footnotetext{
FACULTY OF MINING AND GEOLOGY, SILESIAN UNIVERSITY OF TECHNOLOGY, 44-100 GLIWICE, UL. AKADEMICKA 2, POLAND.
} 
tabelarycznie i w postaci wykresów. Na podstawie charakterystyk gęstości rozkładu frakcji $f(k)$ oraz rozkładu zawartości popiołu $a_{k}(k)$ wyznaczono charakterystyki statyczne jednokomorowego flotownika przepływowego. Znajomość tych zależności pozwoli na lepszą ocenę zjawisk zachodzących w procesie wzbogacania. Może stanowić jedną z podstawowych informacji wykorzystywanych w nadrzędnym systemie sterowania procesu flotacji.

Słowa kluczowe: modele kinetyki flotacji, współczynnik prędkości flotacji, funkcja gęstości rozkładu flotowalności ziaren węgla, flotowniki przepływowe, charakterystyki statyczne flotowników przepływowych

\section{Introduction}

Determination of the static characteristics of the enrichment process in industrial flotation machines is a difficult task due to the influence of many parameters on the course of the process. A parameter that takes into account the impact of all factors is the coefficient of the particles flotation velocity $k$. A feed in under certain conditions by function of the distribution density of the flotability $f(k)$ can be characterized. The function of this type based on the kinetics of separation of the mass of the feed components in the batch flotation process is obtained. This function with the Laplace inverse transformation of the changes of the concentrations of the feed components (in time $t$ ) is related. Determining of the function $f(k)$ indirectly through a kinetics mathematical model $m(t)$ is realized. The components of the concentrate mass $m(t)$ at discrete time moments are obtained. Determined parameters of the kinetics model are simultaneously the parameters of the model of the density function of the distribution of the flotability. Problems related to determination of the flotability spectrum are relatively well resolved. A commonly used approach is adoption the functional form of the mathematical model of the separation of the concentrate mass. This is accomplished for different distribution functions (Brożek \& Młynarczykowska, 2009; Fischera \& Chudacek, 1991; Kalinowski \& Tumidajski, 1995).

The main point in this problem is to select the best fits from accepted models using the commonly used methods of verification. This problem in a lot of the works was discussed (Brożek \& Młynarczykowska, 2009; Imaizumi \& Inoue, 1963; Woodburn \& Loveday, 1965). In these works were assumed that the feed is characterized by a continuous or discrete distribution of particles flotability. In the work (Kalinowski \& Kaula, 2013) a triangular distribution of the function $f(k)$ was proposed. The adoption of such a feature enables the analytical determination of the parameters of the distribution function in the industrial flotation machines.

The shape of the triangular distribution is shown in Fig. 1.

$\mathrm{f}(\mathrm{k})$

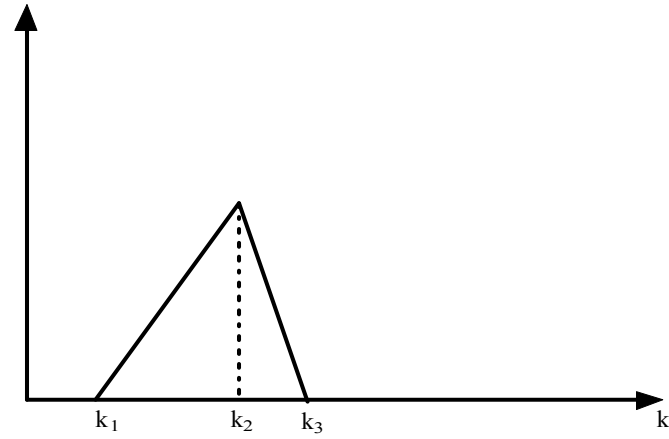

Fig. 1. Distribution of the coal particles flotability $f(k)$ in the shape of the triangle where: $k_{1}, k_{2}, k_{3}$ - the parameters of the triangular distribution 
An important problem is the determination of the concentrate quality. The concentrate quality directly depends on the ash content in the concentrate. In the paper a mathematical model of the separation of the mass of ash at the process of the kinetics of the batch flotation has been proposed. The research at different values of the air flow rate was carried out. On the basis of the experiments of the batch flotation the mass of ash $m_{a}(t)$ at time $t$ can be determined.

Based on measurements of the mass $m(t), m_{a}(t)$ and the parameters of the fraction distribution $f(k)$ we can determine the dependence of the distribution of ash content in the concentrate $a_{k}$ as a function of the coefficient of the flotation velocity $k$.

$$
\begin{gathered}
m(t)=M\left(1-\int_{0}^{\infty} f(k) e^{-k \cdot t} d k\right) \\
m_{a}(t)=M_{a}-M \int_{0}^{\infty} f(k) a_{k}(k) e^{-k \cdot t} d k
\end{gathered}
$$

where:

$M$ - mass of the feed flotable,

$M_{a}$ — mass of ash in part of the feed flotable.

The influence of the coefficient of the flotation velocity on the ash content in the concentrate by the dependence of the second degree polynomial with unknown three parameters $\left(x_{2}, x_{1}, x_{0}\right)$ was determined:

$$
a_{k}(k)=\left(x_{2} \cdot k^{2}+x_{1} \cdot k+x_{0}\right)
$$

The model of the separation of the mass of ash $m_{a}(t)$ in the time $t$ by determining the integral (2) taking into account the equation (3) and the distribution $f(k)$ is obtained:

$$
\left.m_{a}(t)=M_{a}-M \cdot\left\{\begin{array}{l}
\frac{1}{\left(k_{1}-k_{2}\right)\left(k_{1}-k_{3}\right)} e^{-\left(k_{1}+k_{2}\right)(t-\tau)} \cdot \\
(t-\tau)^{4} \\
\left(x_{2} \cdot A+(t-\tau)\left(x_{1} B+(t-\tau) \cdot x_{0} C\right)\right) \\
\frac{1}{\left(k_{2}-k_{3}\right)\left(k_{3}-k_{1}\right)} e^{-\left(k_{2}+k_{3}\right)(t-\tau)} \cdot \\
\left(x_{2} \cdot D+(t-\tau)\left(x_{1} E+(t-\tau) \cdot x_{0} F\right)\right)
\end{array}\right]\right\}
$$

where:

$$
\begin{aligned}
A= & e^{k_{2}(t-\tau)}\left(\begin{array}{l}
6 \\
\left.+4 k_{1}(t-\tau)+k_{1}^{2}(t-\tau)^{2}\right)+
\end{array}\right. \\
& +e^{k_{1}(t-\tau)}\left(\begin{array}{l}
-6-6 k_{2}(t-\tau)-3 k_{2}^{2}(t-\tau)^{2}-k_{2}^{3}(t-\tau)^{3}+ \\
+k_{1}\left((t-\tau)\left(2+2 k_{2}(t-\tau)+k_{2}^{2}(t-\tau)^{2}\right)\right.
\end{array}\right) \\
B= & e^{k_{2}(t-\tau)}\left(\begin{array}{l}
\left.2+k_{1}(t-\tau)\right)+ \\
+
\end{array}\right. \\
& +e^{k_{1}(t-\tau)}\left(\begin{array}{l}
-2-2 k_{2}(t-\tau)-k_{2}^{2}(t-\tau)^{2}+ \\
+k_{1}(t-\tau)\left(1+k_{2}(t-\tau)\right)
\end{array}\right)
\end{aligned}
$$




$$
\begin{aligned}
& C=e^{k_{2}(t-\tau)}+e^{k_{1}(t-\tau)}\left(-1-k_{1}(t-\tau)-k_{2}(t-\tau)\right) \\
& D=e^{k_{2}(t-\tau)}\left(6+4 k_{3}(t-\tau)+k_{3}^{2}(t-\tau)^{2}\right)+ \\
& +e^{k_{3}(t-\tau)}\left(\begin{array}{l}
-6-2 k_{3}(t-\tau)-k_{2}^{3}(t-\tau)^{3}-2 k_{2}(t-\tau) \\
\left(-3+k_{3}(t-\tau)\right)+k_{2}^{2}(t-\tau)^{2}\left(-3+k_{3}(t-\tau)\right)
\end{array}\right) \\
& E=e^{k_{2}(t-\tau)}\left(2+k_{3}(t-\tau)\right)+ \\
& +e^{k_{3}(t-\tau)}\left(\begin{array}{l}
-2+2 k_{3}(t-\tau)-k_{2}^{2}(t-\tau)^{2}+ \\
+k_{2}(t-\tau)\left(-2+k_{3}(t-\tau)\right)
\end{array}\right) \\
& F=e^{k_{2}(t-\tau)}+e^{k_{3}(t-\tau)}\left(-1-k_{2}(t-\tau)+k_{3}(t-\tau)\right)
\end{aligned}
$$

On the basis of the studies (Kalinowski \& Kaula, 1995b, 1996) was found that the flotation kinetics models should take into account the parameter of a transport delay $\tau$. Consideration of the parameter of the transport delay $\tau$ in the model provides the most accurate representation of the flotation kinetics.

\section{Analysis of calculation results}

The measurement data of the mass separation of the concentrate $m(t)$ and mass of the ash $m_{a}(t)$ at time $t$ used to determine the parameters of mathematical models are presented in Table 1 . Detailed description of the batch flotation experiments in which the data were obtained for the calculation was presented in the work (Kalinowski \& Kaula, 1995a). The research was carried out for different values of the air flow rate.

In Table 2 the parameters of the triangular model obtained in the work (Kalinowski \& Kaula, 2013) based on the experiments of the batch coal flotation are shown.

In Table 3 the calculated parameters of the model (4) are shown. These parameters were obtained by the least squares method.

TABLE 1

Results of measuring the mass of the concentrate $m(t)$ and mass of the ash $m_{a}(t)$ in \% to weight of the feed, as a function of time $t$ in $s$, at different values of the air flow rate $V p$ in $10^{-5} \mathrm{~m}^{3} / \mathrm{s}$

\begin{tabular}{|c|c|c|c|c|c|c|}
\hline \hline$t$ & \multicolumn{2}{|c|}{$1 / 3 V p$} & \multicolumn{2}{c|}{$1 / 2 V p$} & \multicolumn{2}{c|}{$V p$} \\
\hline & $m(t)$ & $m_{a}(t)$ & $m(t)$ & $m_{a}(t)$ & $m(t)$ & $m_{a}(t)$ \\
\hline 10 & 29,70 & 1,36 & 31,00 & 1,46 & 45,90 & 1,84 \\
\hline 20 & 54,40 & 2,62 & 58,60 & 2,89 & 74,20 & 3,79 \\
\hline 30 & 70,40 & 3,88 & 72,80 & 3,80 & 82,70 & 4,52 \\
\hline 50 & 81,20 & 4,79 & 82,40 & 4,55 & 86,70 & 4,99 \\
\hline 70 & 85,60 & 5,22 & 85,70 & 4,88 & 88,00 & 5,18 \\
\hline 90 & 87,70 & 5,47 & 87,10 & 5,06 & 88,50 & 5,26 \\
\hline 120 & 88,90 & 5,64 & 88,20 & 5,23 & 89,10 & 5,36 \\
\hline 210 & 90,20 & 5,89 & 89,20 & 5,42 & 89,70 & 5,48 \\
\hline
\end{tabular}


The calculated values of the kinetics parameters of the triangular model based on the experimental results from Table 1

\begin{tabular}{|c|c|c|c|}
\hline \hline$f(k)$ & $1 / 3 V p$ & $1 / 2 V p$ & $V p$ \\
\hline$k_{1}$ & 0,00070 & 0,000001 & 0,000001 \\
\hline$k_{2}$ & 0,0911 & 0,0830 & 0,1340 \\
\hline$k_{3}$ & 0,0911 & 0,1420 & 0,2770 \\
\hline
\end{tabular}

TABLE 3

Parameters of the model of the ash content in the concentrate $a_{k}$

\begin{tabular}{|c|c|c|c|}
\hline \hline & $1 / 3 V p$ & $1 / 2 V p$ & $V p$ \\
\hline$x_{2}$ & 35,056 & 36,582 & 13,244 \\
\hline$x_{1}$ & $-6,226$ & $-6,594$ & $-3,997$ \\
\hline$x_{0}$ & 0,299 & 0,320 & 0,319 \\
\hline
\end{tabular}

Fig. 2 to 4 shows the measurement data and the time courses of separation of the mass of the ash $m_{a}(t)$ for considered cases (Table 1).

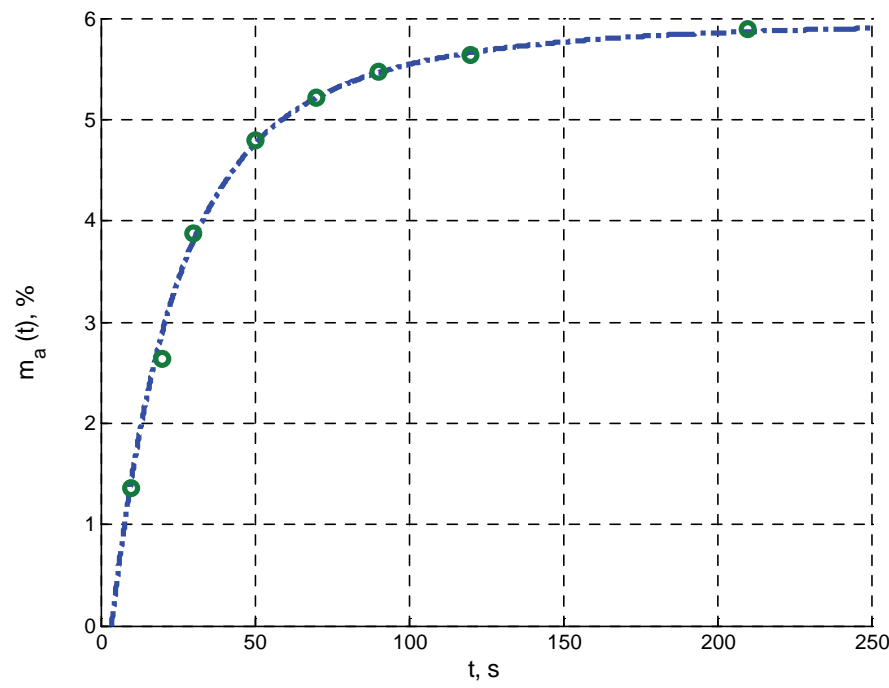

Fig. 2. Time course of the separation of the mass of the ash for $1 / 3 \mathrm{Vp}$

It may be noted that the fitting of the courses of the separation of the mass of the ash $m_{a}(t)$ to the measured data is very accurate. The distributions $f(k)$ and $a_{k}(k)$ in the graphically form are shown (Fig. 5 to Fig. 7) at different values of the air flow rate.

The tested feed material has the most particles with a low ash content as can be seen from the presented drawings (Fig. 5 to Fig. 7). Ash content of the coal particles in dependence of their coefficient of the flotation velocity $k$ at the air flow rate $1 / 3 \mathrm{Vp}$ (Fig. 5) is a monotonic. The 
coefficient of the flotation velocity is lower when the ash content is increasing. Some particles with a higher ash content have obtained higher coefficient of the flotation velocity (due to the physic-chemical phenomena) at air flow rate $1 / 2 \mathrm{Vp}$ and $\mathrm{Vp}$. Assess the impact of the phenomenon based on the steady-state analysis of the flow flotation machines can be made.

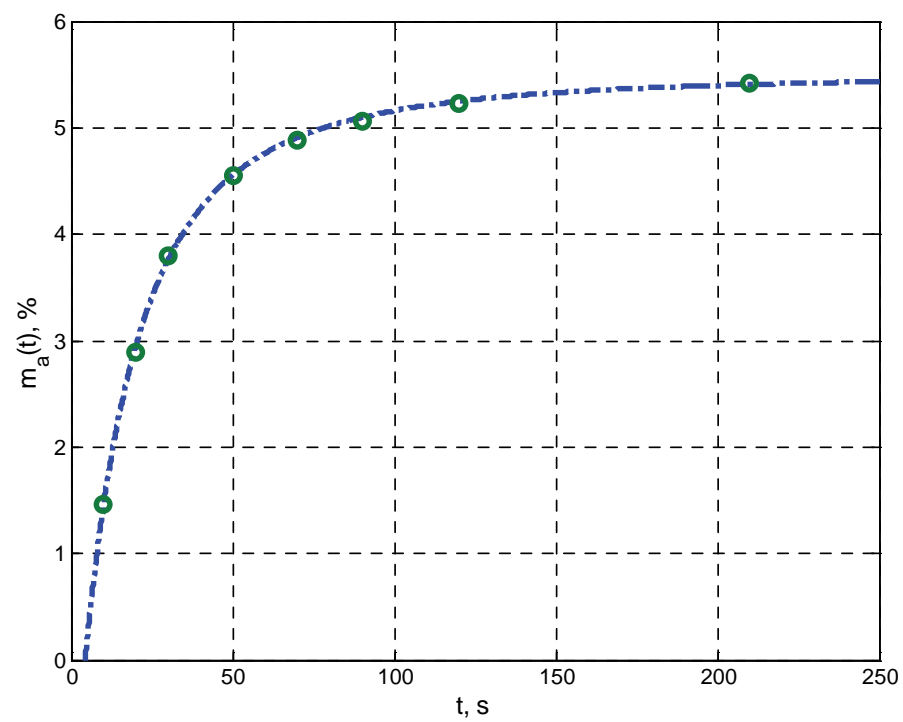

Fig. 3. Time course of the separaton of the mass of the ash for $1 / 2 \mathrm{Vp}$

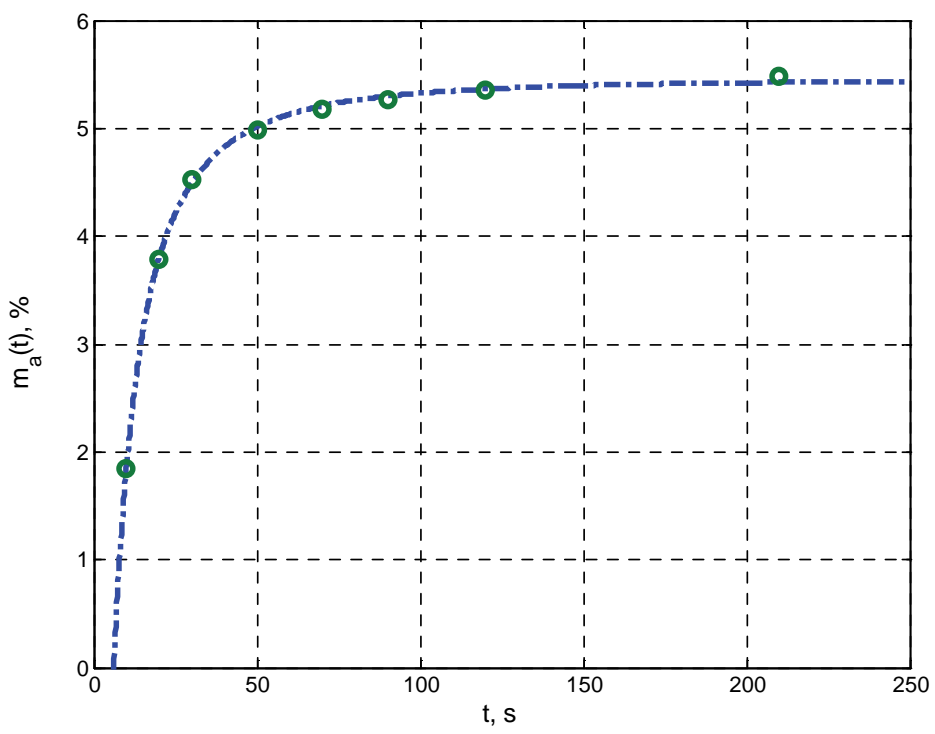

Fig. 4. Time course of the separation of the mass of the ash for $V p$ 

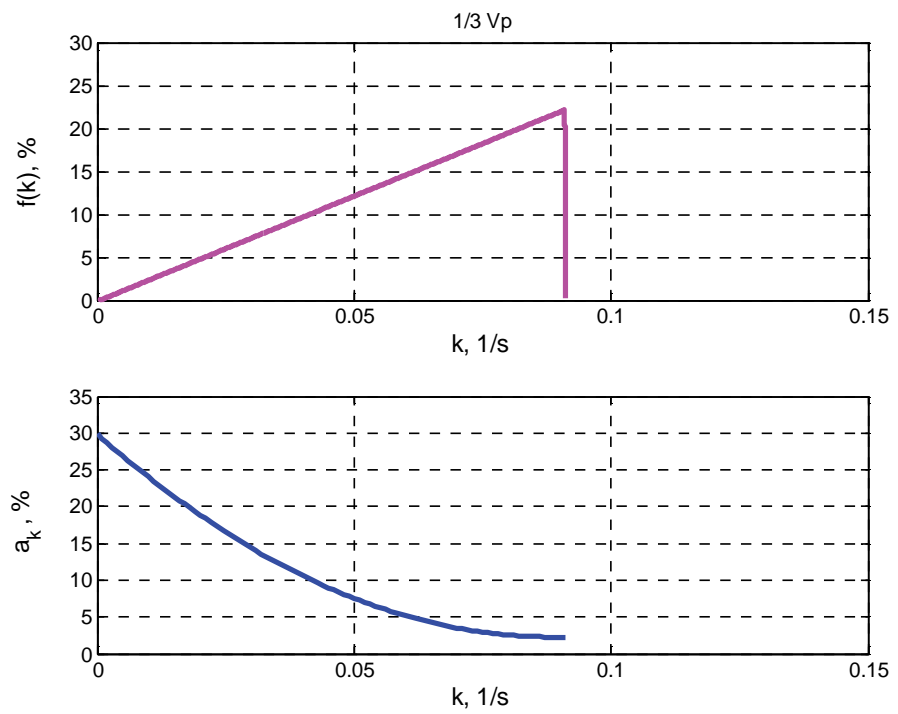

Fig. 5 Distribution functions $f(k)$ and $a_{k}(k)$ for $1 / 3 V p$
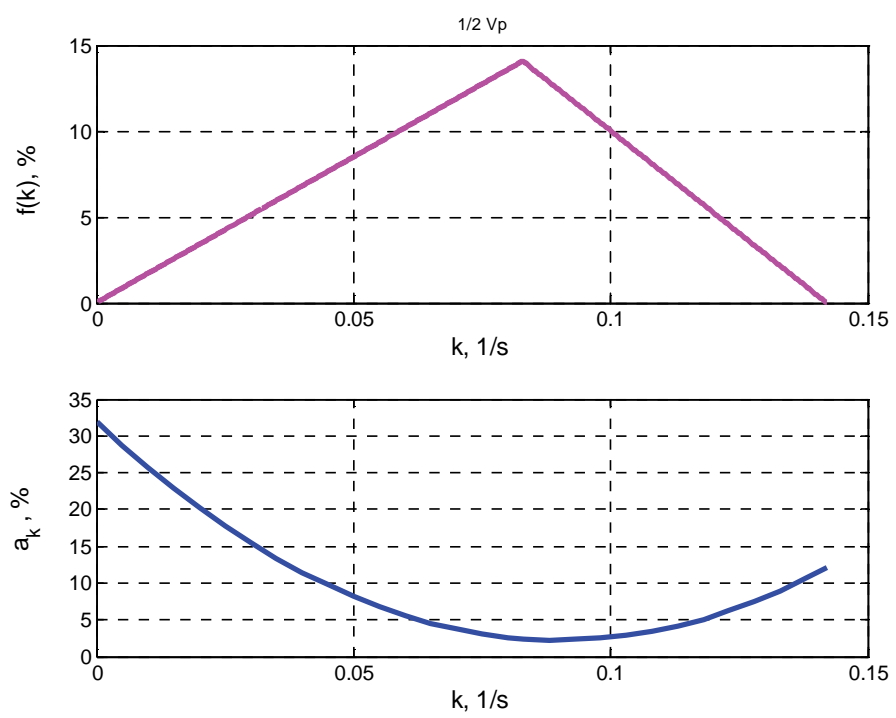

Fig. 6 Distribution functions $f(k)$ and $a_{k}(k)$ for $1 / 2 V p$ 

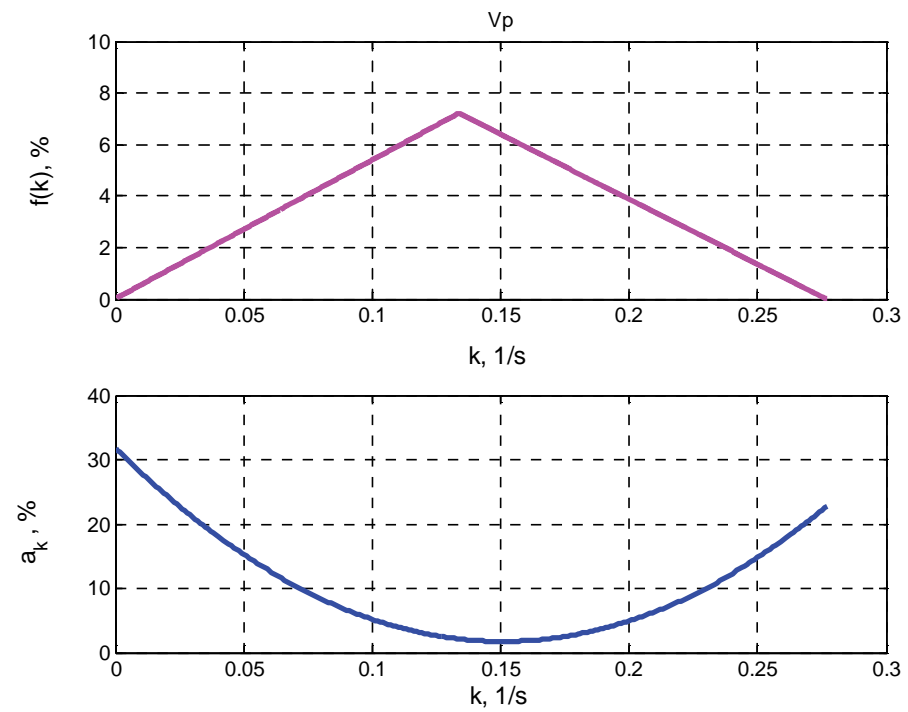

Fig. 7 Distribution functions $f(k)$ and $a_{k}(k)$ for $V p$

\section{Static characteristics of the single-cell flow flotation machine}

The flotation is a continuous process. The basic type of operation of industrial flotation machine is the cell-to-cell flotation. The flotation cells are arranged in series, forming bank. The recovery of concentrate from each flotation cells based on measurements of quality parameters in steady-state can be specified.

The recovery of the concentrate (in the steady-state) single-cell flotation machine can be represented as the following formula:

$$
W_{K}=\int_{k_{1}}^{k_{3}} \frac{\frac{k}{D_{o}}}{1+\frac{k}{D_{o}}} f(k) d k
$$

The ash content in the concentrate can be represented by the formula:

$$
A_{K}=\frac{\int_{k_{1}}^{k_{3}} \frac{\frac{k}{D_{o}}}{1+\frac{k}{D_{o}}} a(k) f(k) d k}{\int_{k_{1}}^{k_{3}} \frac{\frac{k}{D_{o}}}{1+\frac{k}{D_{o}}} f(k) d k}
$$


where:

$D_{o}$ - parameter which characterize the outflow of the particles from the tailings zone, $1 / \mathrm{s}$ (it is the inverse of the average residence time of the particles in the flotation cell),

$k$ - coefficient of the flotation velocity, $1 / \mathrm{s}$.

In Fig. 8 and Fig. 9 the recovery of the concentrate and ash content in the concentrate of the single-cell flotation machine are shown. The calculation results in the graphs in a generalized form are presented. Values of the recovery to the part of the feed flotable are referenced $(100 \%$ recovery corresponds to the maximum of the feed floated). The abscissa axis shows the ratio of $D_{o} / k_{3}$.

On the basis of Fig. 10 can be concluded that the recovery of the concentrate with the ash content of $6 \%$ is the highest at the air flow rate of $1 / 2 \mathrm{Vp}$ and is greater than $90 \%$. Recovery is the smallest at $1 / 3 \mathrm{Vp}$ and it is about $80 \%$. Therefore it can be appreciated the occurrence of the minimum. The recovery of the concentrate is much smaller when the ash content is less than 5.5\%. In this case the influence of the air flow rate is other. The obtained results largely correspond to the results of tests carried out in industrial conditions.

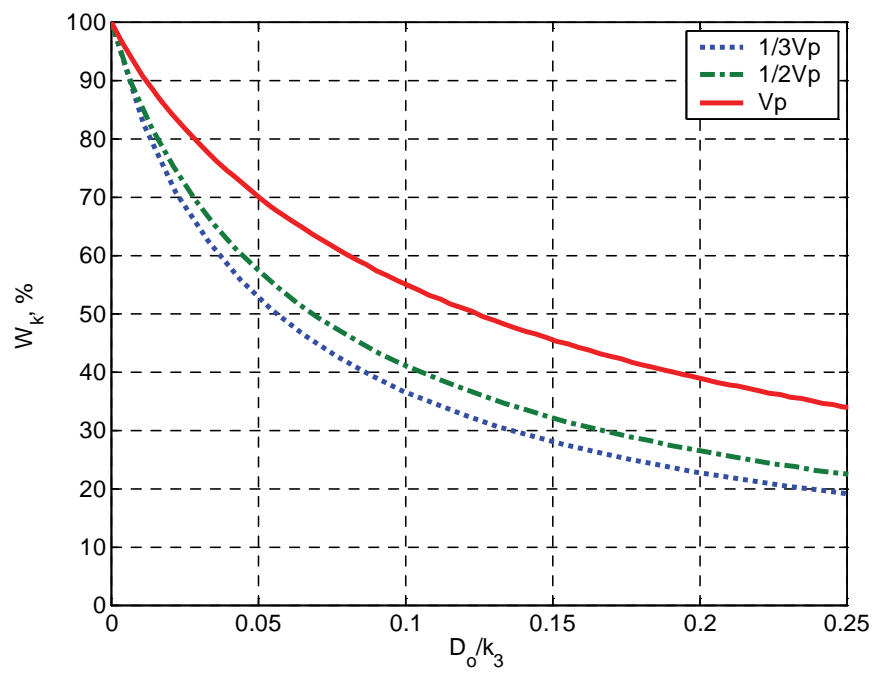

Fig. 8. The recovery of the concentrate of part of the feed flotable as a function of $D_{o} / k_{3}$ 


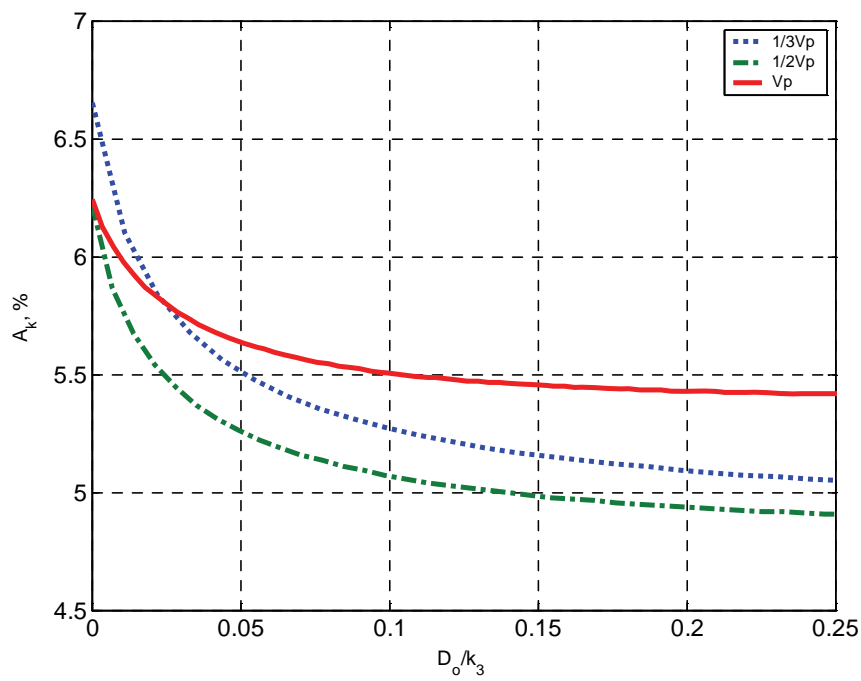

Fig. 9. The ash content in the concentrate of part of the feed flotable as a function of $D_{o} / k_{3}$

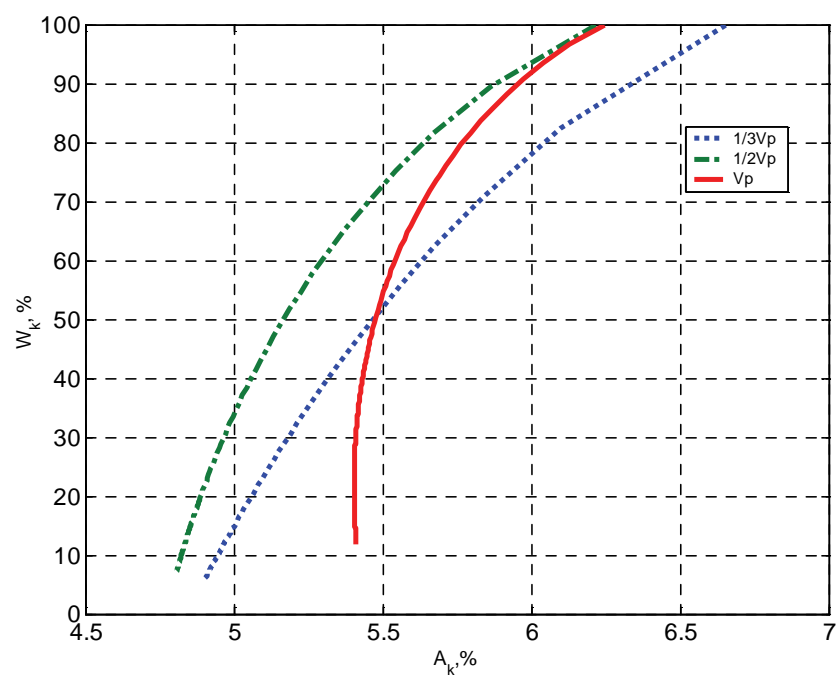

Fig. 10. The recovery as a function of the ash content in the concentrate

\section{Conclusions}

In the theory and a simulation technique of the coal flotation process the density function of the distribution of particles flotability is widely used. The characteristics of this type may be used in the design of the flotation process circuits. 
The study concerning the mathematical models of distribution of the flotability coefficient of the coal particles show that the application of the triangular distribution is justified not only statistically, but it is consistent in a physical sense (feed particles cannot have unlimited coefficient of the flotation velocity).

The distribution of the ash content $a_{k}(k)$ depending on the coefficient of the flotation velocity at the assumed the triangular distribution of the flotability was determined. On the basis of these dependencies the static characteristics of single-cell flotation machine were determined. The analysis of these curves shows that the dependence between the recovery and the ash content in the concentrate on the changes of the air flow rate is extreme. At set point of the ash content in the concentrate can obtain a maximum of the recovery as well as at assumed level of the recovery can obtain a minimum of the ash content in the concentrate. Therefore the air flow rate has a significant impact on the quality of the coal flotation process.

The static characteristics of the recovery and the ash content in the concentrate according to changes in the air flow rate obtained on the basis of simulation studies are similar to designated (by the authors) characteristics based on the research of the industrial flotation machines.

\section{References}

Brożek M., Młynarczykowska A., 2009. Kinetyka flotacji. Wydawnictwo IGSMiE PAN, Kraków.

Fischera M.A., Chudacek M.W., 1991. Batch cell flotation models - A Review. Minerals Engineering 5(1), p. 41-54.

Imaizumi T., Inoue T., 1963. Kinetic considerations of froth flotation. Proc. $6^{\text {th }}$ International Mineral Processing Congress (Cannes), p. 581-593.

Kalinowski K., Kaula R., 1995a. Wpływ natężenia powietrza aeracyjnego na rozkład flotowalności w eksperymentach flotacji cyklicznej węgla. Zeszyty Naukowe Politechniki Śląskiej, seria Górnictwo, z. 225, Gliwice, s. 111-118.

Kalinowski K., Kaula R., 1995b. Transport delay in a mathematical models of batch coal flotation kinetics. Arch. Min. Sci., Vol. 40, p. 339-349.

Kalinowski K., Kaula R., 1996. A Verification Method Of Coal Flotation Kinetic Models. New Trends in Coal Preparation Technologies and Equipment: Proceedings of the $12^{\text {th }}$ International Coal Preparation Congress. Cracow, May 1994, published by Gordon and Brench Publishers, p. 737-740.

Kalinowski K., Kaula R., 2013. Verification of flotation kinetics model for triangular distribution of density function of flotability of coal particles. Arch. Min. Sci., Vol. 58, No 4, p. 1279-1287.

Kalinowski K., Tumidajski T., 1995. Przegląd Modeli matematycznych kinetyki flotacji cyklicznej. Zeszyty Naukowe AGH, Górnictwo, z. 3.

Woodburn E.T., Loveday B.K., 1965. The effect of variable residence time on the performance of a flotation systems. Journal of South African Institute of Mining and Metallurgy, vol. 65, p. 612-628. 